\title{
Application of Weibo in the Ideological and Political Education of Postgraduates in the New Media Age*
}

\author{
Shuang Wu \\ Wuhan University of Science and Technology \\ Wuhan, China 430065
}

\author{
Guodong Wang \\ Wuhan University of Science and Technology \\ Wuhan, China 430065
}

\section{Problems AND Challenges FaCed By THE IDEOLOGICAL AND POLITICAL EDUCATION OF Postgraduates in the New Media Age}

\begin{abstract}
The advent of the new media age is a doubleedged sword, which brings postgraduates convenient accesses to all kinds of information, and also plays an important role in their learning style and life attitude. In addition, various information and communication technology (ICT) platforms are influencing the ways and methods of ideological and political education for postgraduates, but current ideological and political education for postgraduates has not achieve significant effect and remains to be improved. Therefore, how to use the advantages of Weibo and various ICT platforms in the new media age to improve the breadth and depth of ideological and political education for postgraduates is the research focus.
\end{abstract}

Keywords-Weibo; postgraduates; ideological and political education

\section{INTRODUCTION}

With the rapid development of network information technology, the ways for postgraduates to obtain information are no longer limited to classroom teaching, book resources and so on. Especially with the rapid popularization of smartphones in recent years, some postgraduates become the ones publishing, spreading and commending on all kinds of information, which also further facilitate them to get access to information of domestic and foreign politics and affairs, local customs, fashion etc. via We-Media platforms; therefore, in the new media age, We-Media has become an important carrier of ideological and political education for college students. As an information and communication technology platform, Weibo is characterized by convenience, bidirectional propagation and fashionability, in line with the curiosity of postgraduates about new things in life. Through Weibo, postgraduates can learn a lot of information, make comments and express their opinions, which can further promote their communication with others, broaden their horizons and expand their knowledge. Therefore, it is important to study how to realize the combination of Weibo with the ideological and political education for postgraduates to further improve the ideological and political education effect for postgraduates.

*Fund: 2015 postgraduate education teaching reform research project of Wuhan University of Science and Technology - Selection of Ideological and Political Education Carrier for Postgraduates in the New Media Age" (Project No.: Yjg201512).

\section{A. The Ideological and Political Education of Postgraduates is Traditional}

At present, the ideological and political education for postgraduates mainly focuses on classroom teaching, supplemented by guidance from tutors, postgraduate instructors and ideological and political teachers. As a main way for postgraduates to receive ideological and political education before the new media age, this method also plays an active and effective role. However, with the increasing use of new media by postgraduates, postgraduates can receive information from diversified ways, and this weakens the leading function of ideological and political educators in colleges and universities in the context of "We-Media", which puts forward higher requirements and brings new challenges for the teaching-centered mode of education for postgraduates.

\section{B. Postgraduates Receive Information in Diversified Ways, with their Values Showing a Personalized Trend}

In the new media age, information is spreading explosively, social thoughts tend to be diversified, ideological struggles become more complicated, and there are various ways for postgraduates to receive information. All kinds of information come together, positive, which are influencing the ideology of postgraduates in various aspects. In contemporary China, a variety of hot social issues, such as employment and housing price, also are Weibo's trending topics frequently, triggering intense discussions. These problems will erode and flood the developing value of postgraduates, making them begin to think more about personal interests and neglect the professional knowledge and research. As young people, postgraduates are willing to accept new things, but it is urgent for then to pay attention to identifying bad information and preventing ideological depravation. At present, postgraduates show a trend of diversified and personalized values, which poses new challenges to ideological and political education for postgraduates. This requires ideological and political educators make innovation in the educational method, attach importance to the network, stick to the core socialist values, widely provide ideal and faith education, promote the 
educational barrier between teachers and students, and realize immediate and effective interaction between postgraduates and ideological and political educators. postgraduates to establish correct world view, outlook on life and values.

\section{Postgraduates have Academic Stress, and are Easy to Overlook the Ideological and Political Learning}

Postgraduates are generally under stress in specialized course learning, mentor projects, paper publishing, and even all kinds of stress from family and the future development. Such stress tends to cause postgraduates to ignore the ideological and political learning, resulting in ideological waving, and some postgraduates may lose faith, develop non-mainstream values, lack responsibility, become selfseeking, etc.

\section{ADVANTAGES OF USING WEIBO FOR IDEOLOGICAL AND POLITICAL EDUCATION FOR POSTGRADUATES}

\section{A. In the New Media Age, Internet Use is Becoming More and More Popular in China}

According to the 44th China Statistical Report on Internet Development issued by CNNIC, by June 2019, netizens in China had reached 854 million and the Internet penetration rate had reached $61.2 \%$. While the Internet provides convenient communication, it also changes people's habits of receiving and transmitting information. As a new form of social communication, Weibo is popular among young people. According to relevant data, the number of Weibo users has been increasing year by year, including both postgraduates and ideological and political educators. On the Weibo platform, ideological and political educators can interact with postgraduates, lead them to discuss hot issues, express their views, form correct values, and develop a habit of using network resources correctly.

\section{B. Realizing the Extensive Interaction Between Educatees and Educators}

At present, the ideological and political education for postgraduates generally focuses on classroom teaching and extracurricular lectures, mainly characterized by unidirectional infusion by teachers and instructors, as well as knowledge solidifying without timely update. The teaching content mainly focuses on book knowledge and students don't have much right of choice. As a result, the dull teaching content with slow update lacks attraction to postgraduates, and result in low participation of them, so the education result is less satisfactory. As a broad, convenient, free and open platform for knowledge acquisition, Weibo integrates pictures and texts in information dissemination, which can convey information more vividly and effectively. Through social platform accounts, postgraduates can interact with each other, combine ideological and political contents in class with offline communication and express their opinions freely. Such discussion can help students establish correct values, improve their ability to analyze problems, enhance their interest in learning, and encourage them to actively participate in the teaching process. The teaching mode combining ideological and political content in class with offline communication can also eliminate the original

\section{Expanding the Ways and Methods of Ideological and Political Education for Postgraduates}

Standardized, orderly, healthy and positive, open and free Weibo communication can have a positive impact on the formation of correct thoughts and beliefs of postgraduates. By skillfully using social software, postgraduates can keep highly sensitive to the global economic trend, pay attention to current affairs and politics, care for people's livelihood, develop patriotism, and improve their ideological and political quality. For example, the Weibo updates the Hot Search every minute, increases Trending Topics and New Era and sticks public feeling topic, so postgraduates can receive news about current affairs through the platform, and learn about the major strategies, policies and achievements of the Party and the country every day. Through Weibo, students can exchange opinions freely on current events and theoretical points, and achieve ideological and political teaching results through full discussion and communication. In addition, through Weibo, communication among postgraduates is more immediate, equal and sufficient, which promotes the smooth development of ideological and political education for postgraduates.

\section{Promoting Postgraduates' Self-development and Self- improvement}

In the new media age, information is spreading explosively, and postgraduates have many ways to receive information. Such information constantly broadens their cognitive horizon, also keeps them aware of their own shortcomings, and urges them to constantly improve themselves and to actively explore, as well as arousing their strong thirst for knowledge. Only continual self-development can help postgraduates express themselves freely and exchange ideas more deeply on the Weibo platform.

\section{StRATEgIES FOR IDEOLOGICAL AND POLITICAL EDUCATION OF POSTGRADUATES THROUGH WEIBO}

The new media age has brought the ideological and political education for postgraduates many new problems and challenges, as well as many development opportunities. At present, Weibo has increasingly extensive influence on young people, which requires colleges and universities to set up an online education platform for postgraduates to fully exert the propaganda and guidance role of Weibo, and effectively improve the results of ideological and political education for postgraduates.

\section{A. Updating Education Ideas}

Weibo has realized smooth information communication and sharing, built a communication platform between postgraduates and educators, and realized the smooth and allround communication between both sides. Educators can understand the individual needs of the educatees and then take targeted measures to improve the pertinence and 
effectiveness of ideological and political education for postgraduates. The educatees can express their opinions after thinking, and the two sides can communicate freely at one level. Weibo has changed the previous education model, and can fully consider students' actual needs, focus on hot spots, and realize collision of ideas, thus achieving educational effect.

\section{B. Building a Qualified Education Team}

In the new media age, the ideological and political education for postgraduates needs a work team that can keep up with the Times, fully understand the new situation, new characteristics and new requirements of the ideological and political education for postgraduates, and can skillfully use new media platforms to effectively improve the education result; it is necessary to build a highly qualified ideological and political education team which is composed of student counselors, teachers, student leaders and specialists, pay attention to process management, strengthen the guidance to students' use of various microblogs, fully exert the educational role of the microblogs, so as to ensure the educational achievements of ideological and political education for postgraduates.

\section{Improving the Education Mechanism}

The ideological and political education for postgraduates needs to fully implement the concept of "education by all parties in the whole process and in an all-round way". That is, a "quaternity" education mechanism composed by the school, the family, the society and the students shall be established to ensure the continuity of ideological and political education for postgraduates during the period from their admission to graduation. While making use of new media technology, it is necessary to give full play to the basic role of traditional ideological and political education, steadily promote the education work, and lay a solid foundation. In addition, all parties shall use the advantages of Weibo and cooperate with each other to form a joint force of ideological and political education for postgraduates to further improve education achievements.

\section{Creating Education Brands}

It is advisable to consider the requirements and characteristics of ideological and political education for postgraduates in the new media age, set an influential education brand, and use the advantage of rapid and flexible information transmission of Weibo to deeply and extensively penetrate ideological and political education via Weibo into postgraduates; focus on all kinds of patriotic theme education, discussion of current events and hot spots, and personal development, etc. to meet the needs of postgraduates for development and success.

\section{CONCLUSION}

Postgraduates shoulder the important mission of national development and play a key role in building the great Chinese dream. Therefore, it is necessary to expand the scope and depth of ideological and political education for postgraduates; while fully exploring the traditional education methods, give full play to the characteristics and advantages of Weibo, further update ideas, and build a communication platform between educators and postgraduates to realize the collision of ideas and improve education achievements; further strengthen the team building by building a professional ideological and political education team that meets the needs of the Times, and can skillfully use new media technology, especially Weibo, so as to establish good contact with postgraduates, and further improve education achievements; based on the concept of "education by all parties in the whole process and in an all-round way", establish a "quaternity" education mechanism composed by the school, the family, the society and the students to ensure the continuity of ideological and political education for postgraduates, and integrate traditional education method and education via Weibo to jointly improve education achievements; build a group of influential and popular Weibo brands with professional content, precise point of view, heated discussion, from patriotism, current events and hot spots, personal development, etc., to attract postgraduates to learn, discuss and express their opinions actively, so as to improve ideological and political education achievements. By updating education ideas, building a qualified education team, improving the education mechanism and building education brands, colleges and universities can further expand the breadth and depth of the ideological and political education for postgraduates, thus turn a new page of the ideological and political education for postgraduates.

\section{REFERENCES}

[1] Fan Wensheng, Li Xiaomeng. Understanding National People's Congress and Chinese People's Political Consultative Conference through Weibo [J]. Press Outpost, 2010, (5). (in Chinese)

[2] LYU Xinfu. Analysis on the Characteristics of News Communication on Microblog [J]. Today's Massmedia, 2010, (8). (in Chinese)

[3] Zheng Yanlin, Li Luyi. A Preliminary Study on the Application of Weibo in Education [J]. China Education Info, 2010, (2). (in Chinese)

[4] Hao Shengjie. How to deal with the challenge posed by Weibo in ideological and political education [J]. Journal of Yangzhou University (higher education research edition), 2010, (2). (in Chinese)

[5] Kan Daoyuan. Ideological and Political Education Work from the Perspective of Weibo Rising [J]. Journal of Ideological and Political Work Research, 2010, (4). (in Chinese)

[6] Meng Qixuan. The Role of WeChat and Weibo and Strategies for Their Application in Ideological and Political Education for Art and Music Majors in Colleges and Universities in the MicroAge [J]. Western China Quality Education, 2016 (17). (in Chinese)

[7] Wang Xue. Research on the Construction of College Counselors' Micro Blog from the Perspective of Ideological and Political Education [J]. The Guide of Science \& Education, 2016 (04). (in Chinese)

[8] Jia Hewei. Research on the Application of Weibo in Ideological and Political Education in Colleges and Universities [D]. Nanning: Nanning Normal University, 2012. (in Chinese)

[9] Shao Lijun. Research on Ideological and Political Education in Colleges and Universities under the Impact of Weibo Culture [J]. Contemporary Education Research and Teaching Practice, 2017 (9). (in Chinese)

[10] Liu Liu. Research on the Influence and Countermeasures of Weibo Culture on Ideological and Political Education in Colleges and Universities [J]. China Market, 2017 (4). (in Chinese) 
[11] Wang Yulong. Application of Weibo and WeChat in Ideological and Political Education [J]. The Guide of Science \& Education, 2017 (24). (in Chinese) 